\title{
Impacts of Solid Waste on Urban Stream Corridors: Case of Meda Ela Tributary in Upper Mahaweli River in Sri Lanka
}

\author{
Dissanayake L. ${ }^{1 *}$, Nianthi R. ${ }^{1}$ and Gunerathne $\mathbf{K}^{2}{ }^{2}$ \\ ${ }^{1}$ University of Peradeniya, Peradeniya, Sri Lanka \\ ${ }^{2}$ Coast Conservation and Coastal Resource Management Department, Sri Lanka \\ "dissanayakedml2011@gmail.com
}

\begin{abstract}
Impacts caused by solid wastes on urban stream eco-systems are enormous. They directly disturb the natural functions of urban stream eco-systems and harm to both biotic and nonbiotic components of the environment. The main focus of this study is to identify the status and impacts of solid waste profile along the Meda ela stream corridors in the city of Kandy. It is one of the important upper Mahaweli stream corridors which have been extremely threatened by various solid wastes since last three decades. Field measurements, questionnaire survey, observations, laboratory tests and structured discussions with key stakeholders were conducted to identify and analyse the impacts. The study revealed that the main waste management process is being handled by the Kandy Municipal Council. Four (04) main solid waste collection points are identified within the study area. Non point wastes are the most significant waste flows in this stream corridor ecosystem. The main solid waste generation sources are identified as; residential, commercial, industrial, institutional, construction and demolition. Food, plastics, paper, fabric, construction wastes and other various types of debris are identified as main type of solid wastes in the study area. Improper handling of solid waste has severely impacted on the equilibrium of the stream corridor ecosystem particularly on hydraulic, hydrologic, geomorphologic, biological as well as chemical processes. In this situation, the stream corridor ecosystem and stream dwellers are negatively affected due to an inappropriate solid waste management practices in the study area.
\end{abstract}

Keywords: Solid waste, Stream corridor ecosystem, Equilibrium, Meda ela 